Jolanta Barbara Jabłonkowska

https://orcid.org/0000-0002-9121-4172

Academy of Physical Education in Wrocław

Faculty of Physical Education and Sport

jolenda@poczta.onet.pl

Bogusław Stankiewicz

https://orcid.org/0000-0003-0191-2813

Jacob of Paradyż University, Gorzów Wielkopolski

Faculty of Tourism and Health Sciences

bstankiewicz@zut.edu.pl

\title{
MILLENNIAL BACKPACKERS AND RISKS IN TRAVEL: A TYPOLOGICAL APPROACH
}

\begin{abstract}
In the research undertaken, the analysis categorised risk in the experience of the millennial generation of backpackers. An attempt was made to systematise it on the basis of the cognitive as well as emotional characteristics presented by the respondents. The research was conducted between 2018-2020. A non-random selection was used to acquire respondents called snowball sampling. 409 Polish millennial backpackers were found and interviewed online, and from this code keys were then extracted, assigned to meaningful categories, and thematic ranges were defined. The analysis of the collected qualitative material was used to establish a typology of risk for millennial backpacking. Analysis of the collected material on backpacking allowed five coded risk categories to be extracted. The first one was the backpacker's attitude towards travel; the second a search for autonomy and independence; the third selective calculation in terms of 'profit and loss', the balance determining behaviour; the fourth connected with the emotional needs of backpackers and the search for impressions; the fifth with external conditions involving risk related to environmental and cultural features of the reception area. Typological systematization of risk in backpacking allows the needs of this groups of travellers to be understood and service provision to be adapted to the requirements of a particular generation.
\end{abstract}

Keywords: backpacking, risk, millennials.

\section{INTRODUCTION}

The academic literature is dominated by the belief that risk alongside adventure is a vital feature for backpacking trips (Fuchs, 2013; Patyra, Dłużewska, 2015; Wantono, Mckercher, 2020). The motives for undertaking them are varied and for some it becomes a way of creating their identity (Elsrud, 2001); accounts of journeys full of daring activities allow us to present ourselves in an aura of uniqueness and indomitability in backpacker narratives. Risk can also be found in the journey, especially when destinations are areas commonly considered dangerous, and therefore an attribute of strong individuals. According to Leggat and Shaw (2003), the latter option seems to correlate most closely with backpacking, as confronting risks and threats during the journey is a daily reality for backpackers.

There is a rich collection of analyses of risk in the literature on backpacking (Desforges, 2000; Falconer,
2011; Lupton, Tulloch, 2002). Research has examined the relationship between the two (e.g. Jabłonkowska, 2015; Leggat, Shaw, 2003) and described the reasons for it (e.g. Elsrud, 2001; Fuchs, 2013; Kozak, Crotts, Law, 2007; Lepp, Gibson, 2008; Reichel, Fuchs, Uriely, 2007; Ryan, 2003). Backpackers' health problems as a result of taking risky actions (e.g. Piyaphanee et al., 2009; Potasman, Beny, Seligmann, 2000) and the psychological effects, especially related to addiction, have been studied (Bellis, Hughes, Dillon, Copeland, Gates, 2007; Fischer et al., 2010; Jabłonkowska, 2017b).

In this article, research on this issue has been enhanced by two additional threads: the categorising of risk in order to describe the nature of those taken by the millennial generation of backpackers, capturing and specifying the events that the respondents considered risky and thus learning about this particular element. 
The second thread was an attempt to systematise the risk, to put it into a typological framework based on cognitive and emotional aspects.

\section{MILLENNIALS IN TOURISM}

Backpackers from the millennial generation were selected for the research. "Generation Y", "generation MTV", "digital children of the free market", "generation of flip-flops and ipads" (Kubacka-Jasiecka, Passowicz, 2014) or generation 'why' (Kotler, Wong, Saunders, Armstrong, 2005; Tapscott, 2010) are how those born in the last two decades of the 20th century are described (Baran, Kłos, 2014; Fazlagić, 2008). It is a community with a meaningful potential for tourist activity despite financial or time limits (Santos, Veiga, Águas, 2016) who have extensive experience in travelling as tourists from an early age. Many of them have given up mass tourism and look for independent expeditions like backpacking. In their travels they seek personal development, authentic experiences, and want to "immerse themselves" in local cultures and foreign spaces. They often show impatience, require immediate action, results, quick reaction and guaranteed satisfaction (Kowalczyk-Anioł, 2012). They use the internet fluently and in an unlimited way, and have the greatest influence on the changes that have taken place in the tourism market (Iyer, Reisenwitz, 2009; Pendergast, 2010).

\section{RESEARCH MATERIALS AND METHODS}

The research was conducted between 2018-2020 and snowball sampling was used to acquire respondents. In the first stage, a group of 50 people, active on social networking sites (mainly on Facebook), were interviewed online using skype. Only millennials accepted were according to their age and those who declared themselves to be backpackers. At a later stage, the personalities of subsequent backpackers who took part in the survey were obtained via these respondents. As a result, 409 active backpackers who have been undertaking this type of tourism for at least five years were acquired. All were aged between 28 and 40. The number of women who took part in the survey exceeded the number of men and the vast majority had received higher education. The respondents were most often employed on a full-time basis in the state or private sector. No unemployed persons were found (Table 1, 2).

An interview questionnaire (open questions) was used for the purpose of this survey. The questions asked focused on the concepts of risk in backpacking

Table 1. Profile of respondents $(\mathrm{N}=409)$

\begin{tabular}{|c|c|c|c|}
\hline Variable & Category & Number & Percentage \\
\hline \multirow{2}{*}{ Sex } & men & 181 & 44 \\
\hline & women & 228 & 56 \\
\hline \multirow{3}{*}{ Age } & $28-30$ & 205 & 50 \\
\hline & $30-35$ & 188 & 46 \\
\hline & $36-40$ & 16 & 4 \\
\hline \multirow{4}{*}{ Education } & elementary level & 0 & 0 \\
\hline & vocational education & 21 & 5 \\
\hline & secondary education level & 15 & 4 \\
\hline & higher education & 373 & 91 \\
\hline \multirow{5}{*}{ Place of living } & a city of over 500,000 inhabitants & 182 & 45 \\
\hline & a city of 100,000 to 500,000 inhabitants & 128 & 31 \\
\hline & a town of 20,000 to 100,000 inhabitants & 49 & 12 \\
\hline & a town of up to 20,000 inhabitants & 14 & 3 \\
\hline & rural areas & 36 & 9 \\
\hline \multirow{5}{*}{ Socio-economic profile } & public sector employee & 97 & 24 \\
\hline & professional & 41 & 10 \\
\hline & private sector employee & 108 & 26 \\
\hline & self-employed & 163 & 40 \\
\hline & pensioner & 0 & 0 \\
\hline
\end{tabular}

Source: authors. 
Table 2. Travel directions indicated by the respondents

\begin{tabular}{|l|c|}
\hline \multicolumn{1}{|c|}{ Travelling destinations } & Numbers (\%) \\
\hline Croatia, Czech Republic, Slovakia & $37-43$ \\
\hline Hungary, Italy & $26-31$ \\
\hline Austria, Germany, Montenegro, Poland, Romania, Ukraine & $20-25$ \\
\hline Bosnia and Herzegovina, France, Norway, Serbia, Slovenia, Spain & $15-19$ \\
\hline Albania, Belgium, Bulgaria, Denmark, Estonia, Georgia, the Netherlands, Sweden & $10-14$ \\
\hline $\begin{array}{l}\text { Belarus, China, Finland, Greece, Iceland, Israel, Latvia, Lithuania, Macedonia, Morocco, } \\
\text { Moldova, Mongolia, Palestine, Portugal, Russia, Switzerland, Turkey, United Kingdom }\end{array}$ & $5-9$ \\
\hline $\begin{array}{l}\text { Armenia, Azerbaijan, Brazil, Canada, Egypt, India, Iran, Japan, Jersey, Jordan, Kazakhstan, } \\
\text { Kosovo, Kurdistan, Kyrgyzstan, Malaysia, Malta, Monaco, Philippines, Singapore, South Korea, } \\
\text { Tajikistan, Thailand, Tunisia, United Arab Emirates, USA, Uzbekistan, Vietnam }\end{array}$ & $2-4$ \\
\hline
\end{tabular}

Source: authors.

and on exploring and understanding their personal experiences.

The interviews were digitally saved, then transcribed in Microsoft Word format and sent to NVivo 11 Pro to create code keys. Coding the data made it possible to carry out an analysis of the answers given and to identify different problem threads either superior or subsidiary. The codes, in turn, were assigned to the more significant categories. There were five of them.

\section{THE RESULTS}

The analysis of the responses obtained during the survey allows five coded risks to be distinguished in backpacking. The first one is included in the backpacker's travel attitude and - according to the respondents - marks this type of travel in a particular way. The second is found in the search for autonomy and independence. The third selective calculation in terms of 'profit and loss', the balance determining behaviour. The fourth is connected with the emotional needs of backpackers and their rush to experience extraordinary adventures, defined by the authors as searching for impressions. The last category, external conditions, involves risk related to climatic, geographical, natural or environmental conditions in the chosen travel destinations.

\subsection{CATEGORY 1: BACKPACKERS' TRAVEL ATTITUDES}

Topics related to this category refer to areas directly found in the situation of being on the road, such as style of travel, destination, accommodation, transport, activity, visiting either tourist or less popular places, relations with locals. Respondents indicated (78\%) the interaction with the destination that is discovered during their trip. This bond, though marked by risk, allows them to realize their dreams, achieve goals and gain experience:

- "In backpacking, there is really a risk at every step of the way, from getting there, to accommodation, transport, food, meeting others, etc. It's a big undertaking and you only have to count on yourself"1.

- "In backpacking, risk is everything. You never know who you're getting into, where you're going to get to, where you're going to sleep, but that's what's most appealing and fascinating about it".

- "The risk in backpacking is trusting strangers. When you start your journey, you get into a car with a complete stranger at his/her mercy. Continue to visit places of mixed opinion, unpopular, where no one of the healthy senses would look. But we have to, because the backpacker has to take risks, because the effects of this danger are totally worth it".

- "Backpacking in itself is a risk when you are driven by your dreams, you enter an area of strangers - you discover unknown places, you meet unknown people, you enter their culture and life, you do something that is commonly perceived as something potentially dangerous, that can cause trouble, and that is just doing something that others lack courage to do".

The risk is to abandon the zone of comfort, safety and stability and the backpacker then becomes responsible to him/herself for choices. This is an integral part of their identity and they are an integral part of this type of tourism. This forces constant changes to be made:

- "Taking a risk gives us, as backpackers, the guarantee that we will make our dreams and passions come true regardless of personal consequences".

- "We take risks all the time. We choose an overnight stay that a person living in one place wouldn't allow himself or herself, we eat something that the average tourist wouldn't touch, and so on".

- "In backpacking, risk is usually associated with uncertainty. It is not haggling for your life and reaching your destination at all costs, but rather, of course 
in a way, being in the sun and trying to do the impossible".

- "In backpacking we take many risks, it is a form of going beyond comfort".

Therefore, risks in this category can be defined as the range of activities that are undertaken because the journey is related to movement, interaction. It is the vector of change, resulting from the move from a zone of appearances in which the backpacker operates on a daily basis, to a "clash" with another place and a foreign culture.

\subsection{CATEGORY 2: AUTONOMY AND INDEPENDENCE}

The second category includes topics related to freedom and independence: liberation, escape, self-determination, lack of limitation (59\%). Risks in this category should be understood as the need to move away from all that is common, ordinary, everyday, from the norms and social order in which lives are lived. It is a chance to discover a larger range of sensations, to experience emotions, to penetrate unknown places, to contact strangers. This specific act of unrestrained and socially responsible activity allows us to return to the time of adolescence when everything seemed possible:

- "In many cases, risk is just a thought in a person's mind, not a real life-threatening situation. A backpacker sees it differently, risk allows you to experience freedom, adrenaline and independence".

- "For many, risk is connected with uncertainty about what awaits us in the future. And I believe that risk is when you can lose something. In backpacking you almost always gain. Yes, you can lose, but you can in everyday, ordinary life. It seems to me that the risk of traveling as a backpacker is smaller. For example, the risk of a boring life is zero if you travel as a backpacker. Everything depends on what you value most in life. If you value, for example, predictability and a well-organised life, then backpacking is not for you".

- "It's new experiences, escape, madness, detachment from everyday life. Risks in backpacking are almost always associated with unexpected situations that we do not experience every day in traditional life".

- "In my opinion, the risk is to do something without having to think about the effect. It's spontaneity. No norms. Simply total liberation. I never feel as free as when I'm facing the risk of winning. Then I'm like a child fascinated by defeating a dragon".

Taking risks while travelling seems to make life simpler, freer, more authentic. There is a paradox in this statement as risk appears here as a carrier of uncomplicated or trivial experiences. In the experience of travel, however, as one of the respondents stated, it is "marked by the current calculation of the possibility of emergency situations, which we easily assimilate because they teach by play". You really have to have skills, without them you would not be able to cope with difficult situations:

\begin{abstract}
If a person is reasonable and knows how to behave in different situations, and he or she gains this knowledge from travel, then risky situations are less and less difficult, less and less complicated, they can be confronted and this is unusual. Hardship becomes minimal, the same as when you walk around your own place of residence.
\end{abstract}

\subsection{CATEGORY 3: SELECTIVE CALCULATION}

In this third category (44\%), risk is associated with its rationalization as profit or loss through usefulness, minimisation, risks, costs. Risk is a positive value when it is a carrier of opportunity, and therefore arises from weighing up challenges in terms of consequences:

- "These are situations that can significantly change our destination, our meetings and situations in any manner. It is necessary to have the courage to calculate wisely what we can gain and to go that way".

- "Risks in backpacking are not risks, they are more related to the right choice of those better ways to travel".

- "Thoughtful decisions which, despite difficult situations, bring us benefit and satisfaction".

- "A difficulty that we have to overcome in order to gain".

In any other case, it would be a negative loss-making experience. But this is impossible - in the opinion of the respondents - for there is no combination of variable values that would be independent of the situation:

- "The risk is connected with a calculated, well-thoughtout action, taking into account that something may go wrong".

- "We have to be seriously aware that everything can have both negative and positive effects, depending on the situation we find ourselves in. Yes, there may be consequences that we cannot predict. But for the most part, ignoring the dangers involves losing something: health, life or someone, something".

- "I associate risk with such ridiculous behaviour, which can lead to the loss of something that is important to me (health, life, money, valuable objects), etc."

- "Irresponsible action, whose consequences can be very serious".

Therefore, for this group of respondents, risk is an activity to achieve expected effects, a choice that is linked to the dynamically changing conditions of travel, and does not involve conscious or thoughtless exposure to ill-considered decisions. Although such risky (daring) activities can happen in the backpacking community, as the respondents said: 
- "There are backpackers who risk against common sense. In my opinion, this is a show-off. Courage is simply being conscious".

- "If someone thinks that risk in backpacking is exciting, you don't understand anything. It's not about being daredevil. You're not gonna know the world when you're dead. It's not worth jumping into a pool when there's no water".

- "Stupidity and buoyancy. That's how I understand it".

- "Risk is not daring. If that were the case, we would pay the highest price for this ridiculous thing".

\subsection{CATEGORY 4: SEEKING SENSATIONS}

The risk in the statements of the respondents (41\%) was presented as stimuli with a high emotional load. In this category are found topics such as adrenaline, adventure, sensations, exploration, stimulation. In the statements analysed, the respondents appear to have a strong need for external excitement in order to find, using Zuckerman's (1994) terminology, the optimal level of stimulation and excitement for themselves. Without it, life seems stereotypical and boring. For this reason, they engage in risky behaviours, revealing the need to experience otherness, to cross borders on the one hand, and to experience adventure, variety and intensity on the other. It is astonishing that they concentrate their activity around physical risk only, silently omitting the risks in moral, health, social or financial spaces.

The assumption of Fuchs (2013) that backpackers are a separate category of travelers who are different from institutionalised mass tourism in terms of risk behaviour during travel is however wrong. Backpackers are not a homogeneous community in terms of risk perception (Reichel, Fuchs, Uriely, 2007). For this reason, it seems necessary to conduct research to explain the complexity of their attitudes and behaviors related to risk. In order to fill this gap in the literature, the Sensation Seeking Scale developed by Zuckerman could be helpful. When comparing the responses with the scale of sensations proposed by Zuckerman, it is noticeable that two out of four stimuli recorded by him coincide. The first one, experience seeking, is to reject a conformist lifestyle and set off on a journey to seek new experiences:

- "Risk is an attempt at something new, unknown, new experience, breaking down barriers".

- "Risk involves travelling to places that are difficult to reach that other tourists do not reach, and we do not know much about them, but by doing so we get to know foreigners and their culture".

- "It's doing something that's commonly seen as potentially dangerous, that can cause trouble, others don't have the courage to do it, and we go".

- "Exploring, overcoming one's limits and weaknesses".
The second factor (boredom susceptibility) is based on an aversion to routine, avoidance of duties, abandonment of everyday habits, and dissension within existing reality:

- "Risk is a surge of energy when there is a threat, sometimes uncertainty, but then I know that I've broken out of my cage, I'm experiencing something I wouldn't survive in my home".

- "Risk has taught me how to break down my barriers and not get lost in everyday life".

- "For me, risk is liberation from boredom, overcoming my weaknesses, laziness".

- "Achieving higher goals".

In a few statements there was an identification of risk associated with fun $(5.8 \%)$. It is difficult to see in these opinions a direct representation of the third Zuckerman factor (lack of inhibition), the relaxation of social 'brakes'. It is rather a light and pleasant way of spending time on the road without losing control over one's own actions and suffering the negative effects of deceleration:

- "Adrenaline, good fun, emotions, but within reasonable limits".

- "Adventure and memories not to be forgotten, not to be treated! :-)"

- "Where the risk is, there's fun".

- "Joy, laughter, fun and adventure".

Research shows that the perception of risk, as described by the respondents, is not the same as taking risk, and that risk and the search for sensations cannot be regarded as identical.

\subsection{CATEGORY 5: EXTERNAL CONDITIONS}

In the fifth category, the risk is linked to climatic, geographical, natural and environmental conditions. It should be noted that this was indicated least among the respondents, mentioned only by $18 \%$. Included in this category were climate, politics, environment. Respondents described the possibility of losing health, or even life or physical injury, as a result of various unforeseen circumstances, especially connected with an attack from other people or animals:

- "Risks are the possibility of unpleasant and dangerous events, danger situations where the heart beats faster, such as assault, theft, wild animals".

- "Fear of lurking dangers at every turn and helplessness in case of encountering one of them".

- "Discovering unknown places, sometimes wild and unpredictable, it is not known what kind of people will be there".

- "In backpacking the risk is connected with relying on strangers. You can find criminals of all sorts".

Another feeling of threat that respondents have associated with risk includes political or climatic instability in the visited country: 
- "Risks include travelling to countries where the political or climatic situation threatens life and safety".

- "Risk is everywhere, everything is dangerous now. The war in Syria, the conflict in Nagorno-Karabakh, in Africa, in the Middle East, you travel to countries and you don't know if the political situation threatens you not to return from your journey".

- "The political situation and climate problems, floods, hurricanes, fires are all dangerous and put you at risk. But in backpacking, even such risks can lead to achieving something or getting (not material good) with some temporary sacrifice".

- "Danger is not up to me, it is something that cannot be avoided. Political changes in the countries where we are going, some cataclysms. No matter what lifestyle you lead. Potentially, and at home, you could be in danger. So, you have to overcome your fear and go with the knowledge that we are not always safe and will not always be in comfortable situations".

Such a low level of risk related to external conditions is undoubtedly, in the opinion of the authors, a result of the mainstream interest of backpackers. During the journey they focus their perception on gaining experience, discovering new things and experiencing changes. Risk becomes their motivation for travel, and therefore a positive value. This is probably the reason why they have a greater acceptance of risky events, recognizing them as positive travel experiences. Hunter-Jones, Jeffs and Fischbacher-Smith (2007) wrote that the feeling of risk is highly subjective, that the level of tolerance above which it becomes unbearable (it starts to be perceived as negative) is not the same for different groups of tourists. Backpackers seem to have this threshold set very high and this probably explains their low level of concern for external conditions.

\section{DISCUSSION}

World literature on the subject stresses that risks in backpacking affect different spheres of travel, related to backpackers travelling alone in various 'world spaces'; sleeping and eating in places that do not meet basic sanitary or legal requirements; ignorance of health and safety, and without inhibitions (Elsrud, 2001; Issahaku, 2015; Jabłonkowska, 2015, 2017a, 2017b; Watcharapong et al., 2010). Not all of these have been presented in this study, and risk was connected with situations found in the actual nature of their travel style. Additionally, in a way synonymous with risk, were liberation, selfdetermination, usefulness, cost, adrenaline, adventure, exploration. However, in the opinion of the respondents, the boundaries of the pursuit of these values are set by prudence and basic safety principles - the calculation of profit and loss becomes important.
The declarations of the respondents do not indicate those risks which seem obvious from backpacking ${ }^{2}$. None of the respondents $(\mathrm{N}=409)$ mentioned the health risk - associated with being infected during travel, although it is known that there is a relationship between travel and the higher incidence of infectious diseases. Nor did anyone refer to the risk of mental illness (i.e. anxiety, depression, addictions), which can result from experiencing difficult experiences. However, the literature indicates that stress associated with risk has a negative impact on the mental health of backpackers. This issue is presented by the results of Yoda, Yokoyama, Suzuki and Hirao (2017), who pointed out the link between the experience of flooding (in Thailand in 2011) and mental illnesses in tourists travelling around Bangkok at the time. Earlier, similar research in a group of backpackers was conducted by Piyaphanee, Olanwijitwong, Kusolsuk and Silachamroon (2012). Stewart and Leggat (1998) described mental disorders after coming into contact with an exotic culture other than their own. They proved that, in principle, contact with another culture is perceived by backpackers as beneficial, it serves to broaden understanding of the world, build good intercultural relations, shape personality or even escape from the boredom which is part of everyday routine; shock and stress resulting from cultural differences may become a threat to mental health and cause depression, anxiety, insomnia, addictions, hostility or aggression.

In the respondents' narrations there is also no description of cases that would show willingness to take up recreational or sporting risks and establishing relationships with the local community. The respondents did not admit to behaviour such as drug use, alcohol abuse or uncontrolled sexual relations, although this is a theme presented in the literature on this subject and a lot of attention has been devoted to this issue. Among others Fischer et al. (2010) have studied whether sex is a key factor for women to engage in backpacking and a key determinant of their satisfaction with such travel. They pointed out that the choice of destinations, travel partners, accommodation and place of rest for the women surveyed was significant because it was motivated by creating conditions for informal sex (Carr, Poria, 2010).

\section{CONCLUSIONS}

The direction of the research project was not only an academic challenge, but also - in the era of globalized backpacking - important for the service market which can be used in the creation of new tourism products, including for backpackers. The collected empirical material may constitute a valuable source of information addressed to a market segment which is little 
recognized in Polish conditions. The surveys carried out among the respondents of the millennial generation looking for an independent style of travel and innovative concepts of their own, allow this community to be seen with its appreciative approach to risk. The respondents have placed the importance of risk into various categories, the common theme of which has become the rationalisation of experience. The respondents start a backpacking trip (the risk is, in their opinion, related to this style of travel); they move freely without a specific plan, along unpopular routes, penetrate the culture of the visited country and establish contacts with its inhabitants by calculating the balance between profits and losses. They give up their convenience for the authentic experience of doing something, acquiring competences, overcoming their own weaknesses and barriers. One condition has to be met, however, in the risks associated with these needs, the maintenance of security.

When forecasting new services for backpackers, the market of tourism and recreation services must take into account such ideas, which realistically reproduce the 'phenotype' of the contemporary backpacking market and their appetite for risk.

Such products are already slowly being produced, although they are still scarce and do not fill the gap in backpacking needs. In Australia, among others, where tourist attractions have been created allowing 'safe' risks to be experienced, they have been marketed as 'adventurous journeys'. It is an attempt to respond to the need for a specific activity in which risky activities are undertaken, but without real danger or loss. Such activities enable backpackers to create their image as experienced travellers and build a sense of crossing borders, even though the experience is based only on illusion. Furthermore, in New Zealand, a popular destination for backpackers, there are places where you can experience an exciting adventure, not about real danger, but about activity with a thrill.

\section{ENDNOTES}

\footnotetext{
${ }^{1}$ In all respondents' statements quoted in the article, the original spelling has been preserved.

${ }^{2}$ Fuchs (2013) indicates that tourism is characterized by specific characteristics such as immateriality, inseparability, variability and impermanence, and that the tourism product is influenced by specific factors such as bad weather, human relations, striking airport personnel, terror, crime, political unrest, disease and natural disasters. These factors often increase the level of risk perceived by tourists, commonly referred to as "travel risk" or "destination". There are 43 risk factors associated with tourism, from serious events such as natural disasters to trivial matters such as taking part on a trip. Tsaur, Tzeng and Wang (1997) described the risks associated with illness, crime, accidents, hygiene and danger, along with traveling by different means of transport, cultural
}

barriers and uncertainty about laws at the destination. Sönmez and Graefe (1998) detailed risks related to financial, functional and physical, psychological, social, satisfaction, time, health, political instability and terrorism issues.

\section{REFERENCES}

Baran, M., Kłos, M. (2014). Pokolenie Y - prawdy i mity w kontekście zarządzania pokoleniami. Marketing i Rynek, 5, 923-929.

Bellis, M.A., Hughes, K., Dillon, P., Copeland, J., Gates, P. (2007). Effects of backpacking holidays in Australia on alcohol, tobacco and drug use of UK residents. BMC Public Health, 7 (1), 1-10. DOI: https://doi.org/10.1186/1471-2458-7-1

Carr, N., Poria, Y. (2010). Sex and the sexual during peoples leisure and tourism experiences. Newcastle: Cambridge Scholars Publishing.

Desforges, L. (2000). Traveling the world. Identity and travel biography. Annals of Tourism Research, 27 (4), 926-945. DOI: https://doi.org/10.1016/S0160-7383(99)00125-5

Elsrud, T. (2001). Risk creation in traveling. Backpacker adventure narration. Annals of Tourism Research, 28 (3), 597-617. DOI: https://doi.org/10.1016/S0160-7383(00)00061-X

Falconer, E. (2011). Risk, excitement and emotional conflict in women's travel narratives. Manchester: Metropolitan University.

Fazlagić, J.A. (2008). Charakterystyka pokolenia Y. E-mentor, 3 (25), 13-16.

Fischer, J., Rostami, S., Peet, A., Dean, J., Debattista, J., Allen, K. (2010). Sex, drugs and backpacking: Study report. Queensland: Alcohol Education \& Rehabilitation Foundation Ltd.

Fuchs, G. (2013). Low versus high sensation-seeking tourists: A study of backpackers' experience risk perception. International Journal of Tourism Research, 15, 81-92. DOI: https:// doi.org/10.1002/jtr.878

Hunter-Jones, P., Jeffs, A., Fischbacher-Smith, D. (2007). Backpacking your way into crisis: An exploratory study into perceived risk and tourist behavior amongst young people. Journal of Travel \& Tourism Marketing, 23 (2-4), 237-247. DOI: https://doi.org/10.1300/J073v23n02_18

Issahaku, A. (2015). Backpackers' risk perceptions and risk reduction strategies in Ghana. Tourism Management, 49, 99-108. DOI: https://doi.org/10.1016/j.tourman.2015.02.016

Iyer, R., Reisenwitz, T.H. (2009). Differences in generation X and generation Y: Implications for the organization and marketers. Marketing Management Journal, 19 (2), 91-103.

Jabłonkowska, J.B. (2015). Risk-taking factors in backpacker tourism. Zeszyty Naukowe Wyższej Szkoły Humanitas. Pedagogika, $11,119-127$

Jabłonkowska, J.B. (2017a). Backpackerzy polscy a zagraniczni. Wieloaspektowe studium porównawcze. Wrocław: AWF we Wrocławiu.

Jabłonkowska, J.B. (2017b). Alkoholowe, narkotykowe i seksualne „rozhamowanie" backpackerów w świetle międzynarodowych badań porównawczych. Folia Turistica, 43, 153-166. DOI: https://doi.org/10.5604/01.3001.0010.7888

Kotler, P., Wong, V., Saunders, J., Armstrong, G. (2005). Principles of marketing. New Jersey: Prentice Hall FT.

Kowalczyk-Aniol, J. (2012). Tourism trends among generation $Y$ in Poland. Turyzm/Tourism, 22 (2), 15-20. DOI: https://doi. org/10.2478/v10106-012-0007-y

Kozak, M., Crotts, J.C., Law, R. (2007). The impact of the perception of risk on international travellers. International Journal of Tourism Research, 9 (4), 233-242. DOI: https://doi.org/10.1002/jtr.607 
Kubacka-Jasiecka, D., Passowicz, P. (2014). Dorastanie we współczesności. Postawy, wartości i doświadczanie czasu a kryzysy rozwoju pokolenia po transformacji. Czasopismo Psychologiczne - Psychological Journal, 20 (2), 171-182.

Leggat, P.A., Shaw, M.T. (2003). Travel health advice for backpackers. Journal of Travel Medicine, 10 (6), 340-345. DOI: https:// doi.org/10.2310/7060.2003.9361

Lepp, A., Gibson, H. (2008). Sensation seeking and tourism: Tourist role, perception of risk and destination choice. Tourism Management, 29 (4), 740-750. DOI: https://doi.org/10.1016/j. tourman.2007.08.002

Lupton, D., Tulloch, B. (2002). Life would be pretty dull without risk: Voluntary risk-taking and its pleasure. Health, Risk and Society, 4 (2), 113-124. DOI: https://doi.org/10.1080/13698570220137015

Patyra, A., Dłużewska, A. (2015). Backpacking - historia, ramy, rozwój. Turystyka Kulturowa, 11, 40-54.

Pendergast, D. (2010). Getting to know the Y generation. In: P. Benckendorff, G. Moscardo, D. Pendergast (eds), Tourism and generation Y (pp. 1-15). Cambridge: CABI, Oxfordshire. DOI: https://doi.org/10.1079/9781845936013.0001

Piyaphanee, W., Olanwijitwong, J., Kusolsuk, T., Silachamroon, U. (2012). Awareness, practices, and health problems of backpackers traveling during flooding in Thailand during 2011. Southeast Asian Journal Trop Med Public Health, 43 (5), 1193-1200.

Piyaphanee,W., Wattanagoon, Y.,Silachamroon, U., Mansanguan, C., Wichianprasat, P., Walker, E. (2009). Knowledge, attitudes, and practices among foreign backpackers toward malaria risk in southeast Asia. Journal of Travel Medicine, 16 (2), 101-106. DOI: https://doi.org/10.1111/j.1708-8305.2008.00282.x

Potasman, I., Beny, A., Seligmann, H. (2000). Neuropsychiatric problems in 2,500 long-term young travelers to the tropics. Journal Travel Medicine, 7 (1), 5-9. DOI: https://doi. org/10.2310/7060.2000.00002

Reichel, A., Fuchs, G., Uriely, N. (2007). Perceived risk and the non-institutionalized tourist role: The case of Israeli student ex-backpackers. Journal of Travel Research, 46 (2), 217-226. DOI: https://doi.org/10.1177/0047287507299580

Ryan, C. (2003). Risk acceptance in adventure tourism: Paradox and context. In: J. Wilks, S. Page (eds), Managing Tourist Health and Safety in the New milennium (pp. 55-65).
Amsterdam: Elsevier Science. DOI: https://doi.org/10.1016/ B978-0-08-044000-2.50009-2

Santos, M.C., Veiga, C., Águas, P. (2016). Tourism services: Facing the challenge of new tourist profiles. Worldwide Hospitality and Tourism Themes, 8 (6), 654-669. DOI: https://doi.org/10.1108/ WHATT-09-2016-0048

Sönmez, S., Graefe, A. (1998). Determining future travel behavior from past travel experience and perceptions of risk and safety. Journal of Travel Research, 37 (4), 171-177. DOI: https://doi. org/10.1177/004728759803700209

Stewart, L., Leggat, P.A. (1998). Culture shock and travelers. Journal of Travel Medicine, 5, 84-88. DOI: https://doi. org/10.1111/j.1708-8305.1998.tb00469.x

Tapscott, D. (2010). Cyfrowa dorosłość. Jak pokolenie sieci zmienia nasz świat. Tłumaczenie P. Cypryański. Warsaw: WAiP.

Tsaur, S., Tzeng, G., Wang, K. (1997). Evaluating tourist risks from fuzzy perspectives. Annals of Tourism Research, 24 (4), 796-812. DOI: https://doi.org/10.1016/S0160-7383(97)00059-5

Wantono, A., Mckercher, B., (2020) Backpacking and risk perception: The case of solo Asian women. Tourism Recreation Research, 45 (1), 19-29. DOI: https://doi.org/10.1080/0250828 1.2019.1636180

Watcharapong, P., Prapimporn, S., Weerapong, P., Piyada, U., Pongdej, W., Maneerat, B., Thitiya, P., Terapong, T. (2010). Rabies exposure risk among foreign backpackers in Southeast Asia. The American Journal of Tropical Medicine and Hygiene, 82 (6), 1168-1171. DOI: https://doi.org/10.4269/ajtmh.2010.09-0699

Yoda, T., Yokoyama, K., Suzuki, H., Hirao, T. (2017). Relationship between long-term flooding and serious mental illness after the 2011 flood in Thailand. Disaster Medicine and Public Health Preparedness, 11 (3), 300-304. DOI: https://doi. org/10.1017/dmp.2016.148

Zuckerman, M. (1994). Behavioral expressions and biosocial bases of sensation seeking. New York: Cambridge University Press.

Article received:

6 May 2020

Accpeted:

6 November 2020 